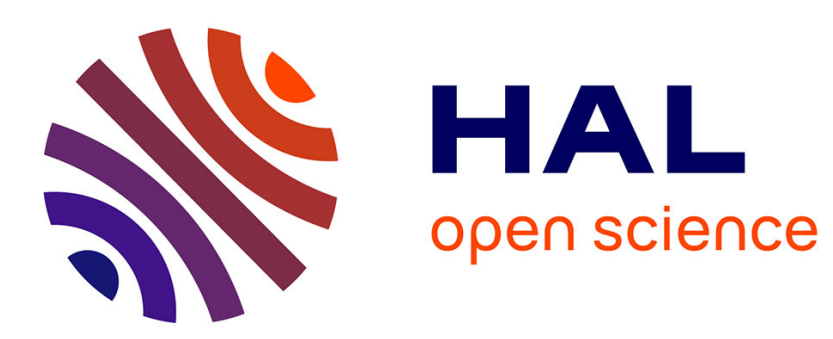

\title{
Estimation of grass intake by lambs using n-alkanes as markers
}

G Béchet, J Tulliez

\section{To cite this version:}

G Béchet, J Tulliez. Estimation of grass intake by lambs using n-alkanes as markers. Annales de zootechnie, 1992, 41 (1), pp.85-85. hal-00888799

\section{HAL Id: hal-00888799 \\ https://hal.science/hal-00888799}

Submitted on 1 Jan 1992

HAL is a multi-disciplinary open access archive for the deposit and dissemination of scientific research documents, whether they are published or not. The documents may come from teaching and research institutions in France or abroad, or from public or private research centers.
L'archive ouverte pluridisciplinaire HAL, est destinée au dépôt et à la diffusion de documents scientifiques de niveau recherche, publiés ou non, émanant des établissements d'enseignement et de recherche français ou étrangers, des laboratoires publics ou privés. 


\title{
COMPORTEMENT ALIMENTAIRE / FEEDING BEHAVIOUR
}

\author{
methode/quantité ingérée/mastication - method/feed intake/mastication
}

\section{Estimation of grass intake by lambs using $n$-alkanes as markers}

\author{
G Béchet ${ }^{1}$, J Tulliez ${ }^{2}$
}

1 INRA-Theix, Laboratoire Lactation et Élevage des Ruminants, 63122 Saint-Genès-Champanelle; ${ }^{2}$ INRA Laboratoire des Xénobiotiques, 31300 Toulouse, France

To estimate herbage intake by lambs at pasture, we have tested the method described by Mayes et al (1986) which employs the natural odd-chain $n$ alkanes (C31 and $\mathrm{C} 33$ ), contained in plant cuticular waxes, as internal markers associated with a dosed adjacent even-chain $n$-alkane (C32) as an external marker.

In July, 9 lambs (5 months old) were housed in digestibility cages for 2 weeks. They received, ad libitum, freshly cut grass from a pasture they had previously grazed, and were dosed at 9.00 with a pellet containing $120 \mathrm{mg} \mathrm{C} 32$. In the second week, for $7 \mathrm{~d}$, a rectal faэces sample was collected from each animal, daily after dosing and intake was measured. The $n$-alkanes in herbage, faeces and pellet were extracted and measured by gas-chromatography, and intake estimated. The dry matter intake (DMI) measured on day $J$ was compared to the DMI estimated from faces collected on days $\mathrm{J}+1$ and $\mathrm{J}+2$

The mean recovery of $n$-alkanes in faeces is : $66.6 \%$ (CV:11.8\%) for C31; $83.4 \%$ (CV:6.2\%) for $\mathrm{C} 32$; and $77.5 \%$
(CV:12.0\%) for $\mathrm{C} 33$. These results are similar to those reported by Dove et al (1989) for C32, but less for the 2 others. The proportion of $\mathrm{C} 32: \mathrm{C}_{33}$ recovery $(1.08$, sd:0.07) is better than C32:C31 (1.26, sd:0.07), and we have used it to estimate intake. The best prediction of dry matter intake measured on day $\mathrm{J}(Y)$ is by measuring $n$-alkanes in faeces collected on the morning of day $\mathrm{J}+1(X)$. The regression equation is : $Y=1.02 X+13.39\left(r^{2}=0.95\right.$; rsd : $24.6 \mathrm{~g}$ ) (fig 1).

This method leads to an accurate estimation of grass intake for lambs at pasture. Nevertheless, the recovery of C33 can be improved by careful selection of the diet sample, in which the concentration of $\mathrm{C} 33$ is to be measured. This may require oesophageal sampling as recommended by Dove et al (1989).

Dove $H$, Mayes RW, Freer $M$, Coombe JB, Foot JZ (1989) Proc XVI Int Grassl Congr, Nice, France, 1093-1094

Mayes RW, Lamb CS, Colgrove PM (1986) $J$ Agric Sci Camb 107, 161-170

$\mathrm{DMl} /$ doy Meosured

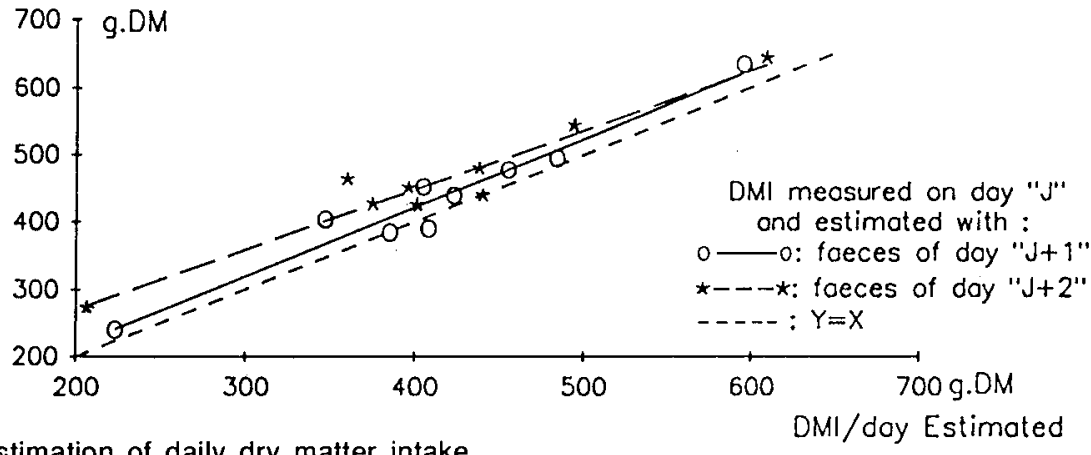

Fig 1. Estimation of daily dry matter intake. 